\title{
Research of the Application of Roasting in the Processing of the Foamy Product of the Process of Bacterial Oxidation of Flotation Concentrate in a Separate Cycle
}

\author{
Rustam Khamidov ${ }^{1}$, Zhakhongir Narzullayev ${ }^{1}$, and Evgeniy Kuznetsov ${ }^{2, *}$ \\ ${ }^{1}$ Navoi State Mining Institute, 210100, Navoi, St. Galaba 27, Uzbekistan \\ ${ }^{2}$ T.F. Gorbachev Kuzbass State Technical University, Mezhdurechensk Branch, 652881, 36 Stroiteley \\ av., Mezhdurechensk, Kemerovo region-Kuzbass, Russia
}

\begin{abstract}
Among the methods of preliminary opening of refractory gold before sorption cyanidation, the technology of bacterial oxidation is widely used today. Although this technology has many advantages, the specialists of most enterprises around the world using this technology are faced with the problem of foaming in bio-oxidation reactors. This article discusses the possibility of using oxidative roasting in the processing of the foam product of the process of bacterial oxidation of flotation concentrate in a separate cycle.
\end{abstract}

\section{Introduction}

Everyone is well aware of the widespread use of gold in human life, the need for it only increases over the years. However, the reserves of gold that can be easily processed are inexorably depleted, and hard-to-process refractory ores are involved in processing [1-3]. At present, the processing of refractory gold sulfide ores and concentrates abroad is carried out using methods of preliminary roasting, autoclave or bacterial leaching followed by cyanidation $[4,5]$. There are also known methods of opening refractory gold such as ultrafine grinding, microwave irradiation, electrohydraulic processing, magnetic pulse processing, etc. [6-9]. Bacterial leaching is the simplest and least expensive technology [10].

Batch foaming is a problem in most bio-oxidation plants. An increase in the level of foam reduces the useful working volume of the reactors, which leads to a decrease in the process time and an increase in the residual sulfur in the bio-oxidation product [11].

Increased foaming leads to the removal of metal from the process into the foam product and its accumulation in the sump of bio-oxidation reactors. The return of the product from the tray to the bio-oxidation process leads to an increase in the pulp flow through the reactors, thereby further reducing the bio-oxidation time and causing an increased carryover of the bacterial culture from the reactors, which also leads to an increase in residual sulfide sulfur [12].

\footnotetext{
* Corresponding author: kevlad@mail.ru
} 


\section{Materials and Methods}

In order to study the structural characteristics of the foam, samples were taken from biooxidation reactors and a study was carried out to determine its composition. The X-ray powder diffraction pattern of a foam sample from bio-oxidation reactors indicates the presence of the following minerals in the sample: pyrite, arsenopyrite, quartz, muscovite / illite, albite, chlorite, stibnite, jarosite, gypsum double-water, talc, anatase, czomolnokite, mercallite, graphite, sulfur, copiapite. X-ray phase analysis in the foam also revealed hematite, chalcocite, gypsum, calcite, chalcocite, alum, soda, dolomite, halite, goethite, and sphalerite.

The total amount of pyrite and arsenopyrite in the sample is $20.4 \%$. Moreover, arsenopyrite is much less than pyrite, which indicates the oxidation of arsenic in the process of bio-oxidation.

The amount of graphite carbon is about $4.6 \%$. A high amorphous background indicates a high content of an amorphous substance in the sample, most likely carbon. There are iron sulfates in the form of jarosite, copiapite, somolnokite, mercallite and gypsum. Antimony sulfide mineral, antimonite, is also observed. Elemental sulfur is also observed in the sample. Mass percentages of minerals in a foam sample from BIOX reactors, calculated as a result of Rietveld's refinement, are shown in Table 1.

Table 1. Mass percentages of minerals in a foam sample from BIOX reactors, calculated as a result of Rietveld's refinement.

\begin{tabular}{|c|c|}
\hline Mineral & Content, \% \\
\hline Pyrite & 19.5 \\
\hline Arsenopyrite & 0.9 \\
\hline Quartz & 12.4 \\
\hline Muscovite / Illite & 29.8 \\
\hline Albite & 9.4 \\
\hline $\mathrm{TiO}_{2}$ & 2.1 \\
\hline Chlorite & 2.2 \\
\hline Stibnite & 0.8 \\
\hline Jarosit & 1.3 \\
\hline Gypsum dihydrate & 0.6 \\
\hline Talc & 5.53 \\
\hline Anataz & 1.46 \\
\hline Szomolnokit & 2.2 \\
\hline Mercallite & 2.55 \\
\hline Graphite & 4.64 \\
\hline Sulfur & 2.15 \\
\hline Copiapite & 2.67 \\
\hline
\end{tabular}

The content of the main valuable component of gold was determined by the method of assay analysis. It was found that the gold content in the primary reactors is about $44 \mathrm{~g} / \mathrm{t}$ 
and its value increases towards the last reactor, where the gold content reaches $286 \mathrm{~g} / \mathrm{t}$. The sample contains silver, the average content of which is about $98 \mathrm{~g} / \mathrm{t}$. Sulfur and carbon contents were determined by combustion on a LECO analyzer, and their values are $10-15 \%$ and $7-20 \%$, respectively (Table 2 ).

Table 2. Initial data of foam bioreactors.

\begin{tabular}{|c|c|c|c|c|c|c|}
\hline \multirow{2}{*}{ Sample name } & \multicolumn{5}{|c|}{ Content of elements in samples } \\
\cline { 2 - 7 } & $\mathbf{A u , g} / \mathbf{t}$ & $\mathbf{A g}, \mathbf{g} / \mathbf{t}$ & $\mathbf{S}_{\text {total, } \%}$ & $\mathbf{S s ,} \%$ & $\mathbf{C}_{\text {total, \% }}$ & $\mathbf{C}_{\text {org, \% }}$ \\
\hline $\begin{array}{c}\text { Reactor - I, II, III } \\
\text { (primary) }\end{array}$ & 44.3 & 34.7 & 15.29 & 10.99 & 7.09 & 5.78 \\
\hline Reactor - IV & 183.5 & 88.63 & 18.04 & 11.94 & 18.26 & 15.48 \\
\hline Reactor - V & 230.2 & 116.1 & 15.76 & 10.01 & 17.14 & 16.44 \\
\hline Reactor - VI & 286.5 & 164 & 10.57 & 6.83 & 20.29 & 19.7 \\
\hline
\end{tabular}

The above factors confirm the feasibility of the way of withdrawal and separate processing of foam from bio-oxidation reactors. The high content of sulfur and carbon indicates the need for oxidative roasting with further sorption cyanidation of the cinder [13]. The results of research on firing the foam product of bio-oxidation reactors followed by sorption cyanidation are presented in Table 3 . The studies were carried out on a sample taken from reactor 6 , since it has the highest content of the valuable component.

Table 3. Results of firing the foam product of bio-oxidation reactors followed by sorption cyanidation.

\begin{tabular}{|c|c|c|c|c|c|c|}
\hline $\begin{array}{c}\text { Sample } \\
\text { name }\end{array}$ & $\mathbf{A u}, \mathbf{g} / \mathbf{t}$ & $\mathbf{A g}, \mathbf{g} / \mathbf{t}$ & $\mathrm{S}_{\text {total }}, \%$ & Ss, \% & $\mathrm{C}_{\text {total, }} \%$ & $\begin{array}{c}\text { Gold recovery } \\
\text { during sorption } \\
\text { cyanidation of } \\
\text { cinder, } \%\end{array}$ \\
\hline \multirow{4}{*}{$\begin{array}{c}\text { Reactor - } \\
\text { VI }\end{array}$} & & ontent of & ments bef & e roast & & \multirow{4}{*}{93.17} \\
\hline & 286.5 & 10.57 & 6.83 & 20.29 & 19.7 & \\
\hline & \multicolumn{5}{|c|}{ Content of elements after roasting } & \\
\hline & 328.10 & 2.23 & 0.06 & 0.17 & 0.08 & \\
\hline
\end{tabular}

\section{Results}

Studies on the separate processing of the foam product of the bio-oxidation process have shown that sulfide sulfur and organic carbon are almost completely oxidized, releasing the gold contained in them, which is confirmed by the high extraction of the valuable component of $93.17 \%$ during sorption cyanidation. Thus, the expediency of processing the foam product of the bio-oxidation process in a separate cycle with metal recovery up to $93.17 \%$ has been proved. It is expected that the process of sorption cyanidation of biokek will also show a relative increase, since the main part of the sorption active natural carbon in the pulp is concentrated in the bio-oxidation foam. 


\section{Discussion}

Due to the separate processing of the foam product of the bio-oxidation process, the problem of the formed foam during the process is solved, and, as a result, the efficiency of the bacterial oxidation process increases.

\section{References}

1. W.J. Li, Y.S. Song, Y. Chen, L.L. Cai, G.Y. Zhou, IOP Conf. Series Mater. Sci. Eng., 231, 12169 (2017)

2. X. Guo, Y. Xin, H. Wang, Nonferrous Metals Soc. China, 27, 1888-1895 (2017)

3. A.Ya. Baudouin, S.B. Fokina, G.V. Petrov, M.A. Serebryakov, Modern problems of science and education, 6 (2014) URL: https://www.scienceeducation.ru/ru/article/view?id=15619

4. R.K. Asamoah, W. Skinner, J. Addai-Mensah, Powder Technol. 331, 258-269 (2018)

5. Xu Wang, Wenqing Qin, Fen Jiao, Congren Yang, Yanfang Cui, Wei, Zhengquan Zhang and Hao Song, Mineralogy and Pretreatment of a Refractory Gold Deposit in Zambia (Minerals, Manchester, 2019). URL: https://www.mdpi.com/2075163X/9/7/406/pdf

6. O. Celep, P. Altınkaya, E.Y. Yazici, H. Deveci, Effect of ultrafine-grinding on cyanide leaching of copper bearing pyritic gold concentrate (15th International Mineral Processing Symposium, Istanbul, 2016)

7. S. Ellis, Ultra-Fine Grinding - A Practical Alternative to Oxidative Treatment of Refractory Gold Ores. URL: https://www.isamill.com

8. Choi N.C., Kim B.J., Cho K., Lee S., C.Y. Park, Metals, 1, 404 (2017)

9. Xiaoliang Zhang, Chunbao Sun, Yi Xing, Jue Kou, Min Su, Hydrometallurg, 180, 210-220 (2018)

10. L.N. Krylova, K.A. Wigandt, L.E. Sarokhanova, E.V. Adamov, Zheng Zhihong, Nonferrous metals, 11, 26 (2013)

11. K.S. Sanakulov, U.A. Ergashev, R.A. Khamidov, Foaming problem in biooxidation reactors (UGDS, Tashkent, 2020)

12. K.S. Sanakulov, U.A. Ergashev, K.U. Gafurov, Mining Journal, 1(special issue), 58-63 (2017)

13. J. Hammerschmidt, J. Guntner, B. Kerstiens, A. Charitos, Roasting of Gold Ore in the Circulating Fluidized-Bed Technology in Gold Ore Processing (Adams, London, 2016) 